\title{
Pengaruh Model Pembelajaran Thinking Aloud Pair Problem Solving (TAPPS)terhadap Hasil Belajar Fisika Siswa SMP Negeri 14 Palu
}

\author{
Moh Kurniawan,I Komang Werdhianadan Marungkil Pasaribu \\ mohkurniawan394@gmail.com \\ Program Studi Pendidikan Fisika FKIP Universitas Tadulako \\ Jl. Soekarno Hatta Km. 9 Kampus Bumi Tadulako Tondo Palu - Sulawesi Tengah
}

\begin{abstract}
Abstrak - Penelitian ini bertujuan untuk mengetahui ada tidaknya pengaruh model pembelajaran Thinking Aloud Pair Problem Solving (TAPPS) terhadap hasil belajar fisika siswa SMP Negeri 14 Palu. Jenis penelitian ini adalah kuasi- eksperimen dengan rancangan prates- pascates yang tidak ekuivalen. Penentuan sampel dengan pertimbangan tertentu kemudian dibagi menjadi dua kelas yaitu VIIIB ${ }^{1}$ dengan jumlah 24 siswa sebagai kelas eksperimen dan kelas VIIIB ${ }^{3}$ dengan jumlah 24 siswa sebagai kelas kontrol. Instrumen penelitian adalah tes pilihan ganda sebanyak 20 soal. Hasil analisa data diperoleh rerata skor kelas eksperimen adalah 12,87 dan standar deviasi 3,06 untuk kelas kontrol diperoleh rerata skor yaitu 11,16 dan standar deviasi 2,79. Hasil penelitian ini diuji dengan menggunakan Uji-t(dua pihak). Berdasarkan perhitungan diperoleh nilai $t_{\text {hitung }}=2,57$ lebih besar daridari $t_{\text {tabel }}=1,67$. Hal ini menunjukkan bahwa $t_{\text {hitung }}$ barada diluar daerah penerimaan $\mathrm{H}_{0}$. Sehingga, hipotesis yang menyatakan hasil belajar fisika siswa dengan model pembelajaran TAPPS lebih baik daripada hasil belajar fisika siswa yang menggunakan model konvensional. Maka dapat disimpulkan hasil belajar fisika antara siswa yang menggunakan model pembelajaran TAPPS lebih baik dari siswa yang menggunakan pembelajaran konvensional.
\end{abstract}

Kata Kunci: Thinking Aloud Pair Problem Solving (TAPPS), Hasil Belajar Fisika.

\section{PENDAHULUAN}

Dewasa ini pembelajaran yang dilakukan di dalam kelas masih pada tahap pengetahuan, hal ini terjadi salah satunya disebabkanpembelajaran masih bersifat hapalan dari buku pelajaran. Kelemahan pembelajaran yang masih tampak adalah pembelajaran dikuasai oleh pendekatan ekspositori dan pemakaian buku teks, sehingga tidak mendorong siswa untuk berfikir[1].

Cara belajar merupakan suatu cara bagaimana siswa melaksanakan kegiatan belajar misalnya bagaimana mereka mempersiapkan belajar, mengikuti pelajaran, aktivitas belajar mandiri yang dilakukan, pola belajar mereka, cara mengikuti ujian. Kualitas cara belajar akan menentukan kualitas hasil belajar yang diperoleh. Cara belajar yang baik akan menyebabkan berhasilnya belajar, sebaliknya cara belajar yang buruk akan menyebabkan kurang berhasil atau gagalnya belajar[2].

Ketidaktepatan pemilihan model pembelajaran yang dilakukan oleh guru menyebabkan pelajaran fisika mendapat kesan kurang baik dari siswa. Penyajian materi fisika yang kurang menarik dan membosankan, akhirnya terkesansulit dan menakutkan bagi siswa, akibatnya banyak siswa yang kurang menguasaidasar dari pelajaran fisika, sehingga siswa tersebut tidak tertarik lagi mempelajarinya.

Model belajar guru yang kurang baik akan mempengaruhi belajar siswa yang tidak baik pula. Model mengajar yang kurang baik itu dapat terjadi misalnya karena guru kurang persiapan dan kurang menguasai bahan pelajaran sehingga guru tersebut tidak menyajikan materi dengan jelas atau sikap guru terhadap siswa atau terhadap mata pelajaran itu sendiri tidak baik, sehingga siswa kurang senang terhadap mata pelajaran atau gurunya, akibatnya siswa malas untuk belajar. Guru biasa mengajar dengan metode ceramah saja, sehingga menyebabkan siswa menjadi bosan, mengantuk, pasif dan hanya mencatat saja. Sehingga dapat menyebabkan rendahnya hasil belajar siswa[3].

Berdasarkan berbagai faktor penyebab rendahnya hasil belajar tersebut, dapat diasumsikan bahwa factor utama yang menyebabkan rendahnya mutu pembelajaran karena kekurang tepatan guru dalam memilih pendekatan pembelajaran dan kekurang mampuan guru dalam memotivasi belajar siswa. Faktor pendekatan belajar dan motivasi merupakan factor utama yang mempengaruhi hasil belajar.

Pembelajaran konvensional adalah pembelajaran dengan menggunakan metode yang biasa dilakukan oleh guru yaitu memberi 
p-ISSN 2338-3240, e-ISSN 2580-5924

materi melalui ceramah, latihan soal kemudian pemberian tugas. Pada umumnya pembelajaran konvensional lebih terpusat pada guru. Akibatnya terjadi praktik belajar mengajar yang kurang optimal karena guru membuat siswa pasif.[4]

Pembelajaran yang dilaksanakan dapat diketahui hasilnya dengan diadakan evaluasi hasil belajar yang meliputi aspek kognitif, afektif, dan psikomotorik. Evaluasi hasil belajar bertujuan mengetahui kemajuan-kemajuan dan kelemahan siswa, guru, proses belajar mengajar beserta sebab akibatnya, sehingga siswa dapat mengetahui langkah apa yang akan diambil untuk meningkatkan hasil belajarnya. Dalam proses belajar mengajar dapat digunakan banyak pendekatan pembelajaran. Agar diperoleh hasil yang optimal diperlukan pendekatan yang tepat untuk mengajarkan suatu pengetahuan atau materi sehingga hasilnya sesuai dengan yang diharapkan.

Berdasarkan paparan di atas, dilakukan penelitian terkait dengan hasil belajar fisika pada materi gaya. Permasalahan hasil belajar diatas diatasi, dengan menggunakan model pembelajaran yang mampu meningkatkan aktivitas siswa di dalam kelas yaitu menggunakan model pembelajaran Thinking Aloud Pair Problem Solving (TAPPS). Model pembelajaran(TAPPS) merupakan salah satu pengembangan dari model pembelajaran (cooperative), dimana siswa belajar secara berkelompok (cooperative). Siswa dilatih dan dibiasakan untuk saling bertukar pengetahuan, berdiskusi secara komunikatif, serta berbagi tugas dan tanggung jawab di dalam kelompokkelompok yang telah ditentukan.

Keberhasilan belajar menurut model belajar ini bukan semata-mata ditentukan oleh kemampuan individu secara utuh, melainkan perolehan belajar itu akan semakin baik apabila dilakukan secara bersama-sama dalam kelompok-kelompok belajar kecil yang terstruktur dengan baik. Melalui belajar dari teman yang sebaya dan dibawah bimbingan guru, maka proses penerimaan dan pemahaman siswa akan semakin mudah dan cepat terhadap materi yang dipelajari.

Model pembelajaran (TAPPS) diharapkan dapat memberikan dampak positif terhadap pembelajaran khususnya pelajaran fisika. Dengan model pembelajaran ini memberikan peran dan tanggung jawab kepada tiap siswa di dalam kelompok yang telah ditentukan untuk menjawab pertanyaan dan menyelesaikan masalah-masalah yang diberikan dalam kelompok secara komunikatif dan bersamasama.
Berdasarkan penjelasan diatas maka peneliti mengkomparasikan hasil belajar antara kelompok siswa yang diberi perlakuan model pembelajaran Thinking Aloud Pair Problem Solving (TAPPS) dengan kelompok siswa yang diberi perlakuan model konvensional pada materi gaya dan penerapannya di SMP Negeri 14 Palu.

\section{METODE PENELITIAN}

Penelitian yang digunakan adalah jenis penelitian dengan rancangan eksperimen kuasi (quasi-experimental design)

Desain penelitian yang digunakan yaitu the non equivalent control group design. [5]Desain penelitian yang digunakan dapat dilukiskan seperti pada Tabel 1.

TABEL 1 DESAIN PENELITIAN

\begin{tabular}{cccc}
\hline Kelompok & Prates & Perlakuan & Pascates \\
\hline Eksperimen & $\mathrm{O}_{1}$ & $\mathrm{X}_{1}$ & $\mathrm{O}_{1}$ \\
Kontrol & $\mathrm{O}_{1}$ & & $\mathrm{O}_{1}$ \\
\hline
\end{tabular}

Keterangan:

$\mathrm{X}_{1}$ : Model Thinking Aloud Pair Problem Solving

$\mathrm{O}_{1}$ : Tes awal dan tes akhir

Penelitian dilakukan di SMP Negeri 14 Palu. Populasi dalam penelitian ini adalah seluruh siswa kelas VIII SMPNegeri 14 Palu tahun pelajaran 2016/2017 yang terdiri dari 7 kelas. Sampel dalam penelitian ini adalah kelas VIII B1 yang berjumlah 24 siswa dan VIII B3 yang berjumlah 24 siswa. Teknik pengumpulan sampel yang digunakan adalah purposive sampling, yaituteknik penentuan sampel dengan pertimbangan tertentu.

Instrumen yang digunakan dalam penelitian ini adalah tes pilihan ganda untuk melihat hasil belajar siswa pada mata pelajaran fisikayang telah divalidasi oleh validator ahli. Analisis data dilakukan dengan menganalisis instrumen terlebih dahulu menggunakan uji validitas item dan reliabilitas tes yang kemudian dengan menganalisis data hasil penelitian menggunakan uji normalitas, uji homogenitas dan uji hipotesis.

\section{HASIL DAN PEMBAHASAN}

\section{A. Hasil Penelitian}

Suatu instrumen dikatakan valid apabila instrument tersebut dapat mengukur apa yang seharusnya diukur. Pada penelitian ini proses validasi dilakukan oleh validator ahli. Dimana soal yang telah dibuat dikonsultasikan kepada validator ahli kemudian divalidasi dan direvisi. Validasi yang diuji adalah validasi ahli dan validasi konstruksi. Dari hasil validasi oleh 
p-ISSN 2338-3240, e-ISSN 2580-5924

validator ahli, diperoleh 31 soal yang selanjutnya akan dilanjutkan pada tahap uji coba soal. Soal yang telah di validasi oleh ahli kemudian diujicobakan di kelas IXSMP Negeri 14 Palu pada tanggal 9 Agustus 2016 yang diikuti oleh 34 orang siswa. Dimana pemilihan kelas ini karena di kelas tersebut telah mempelajari materi gaya dan penerapannya.

Adapun instrumen yang diujikan terdiri atas 31 item soal. Uji coba dilakukan dengan tujuan untuk mengetahui validitas, reliabilitas, daya pembeda dan tingkat kesulitan dari instrumen tersebut.

Preetest digunakan untuk mengetahui kemampuan awal siswa sebelum mengikuti pembelajaran. Hasil pengolahan data preetest dan posttest untuk masing-masing kelas, yaitu kelas eksperimen dan kelas kontrol, diperoleh nilai maksimum, nilai minimum, nilai rata-rata dan simpangan bakuseperti terlihat pada Tabel 2.

TABEL 2 DESKRIPSI SKOR TES HASIL BELAJAR FISIKA UNTUK KELAS

\begin{tabular}{lcccc}
\multicolumn{5}{c}{ EKSPERIMEN DAN KELAS KONTROL } \\
\cline { 2 - 5 } Uraian & Preetest & \multicolumn{2}{c}{ Posttest } \\
\cline { 2 - 5 } & Eksperimen & Kontrol & Eksperimen & Kontrol \\
\hline $\begin{array}{l}\text { Sampel } \\
(\mathrm{n})\end{array}$ & 24 & 24 & 24 & 24 \\
$\begin{array}{l}\text { Nilai } \\
\text { maksimum }\end{array}$ & 15 & 14 & 18 & 16 \\
$\begin{array}{l}\text { Nilai } \\
\text { minimum } \\
\begin{array}{l}\text { Skor rata- } \\
\text { rata }\end{array}\end{array}$ & 9,00 & 8,00 & 12,87 & 11,16 \\
$\begin{array}{l}\text { Standar } \\
\text { deviasi }\end{array}$ & 3,14 & 3,07 & 3,06 & 2,79 \\
\hline
\end{tabular}

Uji normalitas pada penelitian ini menggunakan uji Chi-kuadrat dengan kriteria penerimaan $\mathrm{X}^{2}$ Hitung $<\mathrm{X}^{2}$ tabel, taraf signifikansi a $=0,05$ dan derajat kebebasan $\mathrm{dk}=\mathrm{k}-3$. Berdasarkan hasil perhitungan untuk posttest nilai $\chi^{2}$ hitung untuk kelas eksperimen adalah sebesar 3,15 dan untuk kelas kontrol sebesar 2,03 dengan $\chi^{2}$ tabel sebesar 7,81. Data tersebut disajikan pada tabel 3 .

TABEL 3 HASIL UJI NORMALITASPOSTTESTKELAS EKSPERIMEN DAN KELAS KONTROL

\begin{tabular}{lllll}
\hline No. & Kelas & $\begin{array}{l}\text { Nilai } \\
\mathrm{X}^{2} \text { Hitung }\end{array}$ & $\begin{array}{l}\text { Nilai } \\
\mathrm{X}^{2} \text { Tabel } \\
=0,05)\end{array}$ & Keputusan \\
\hline 1 & $\begin{array}{l}\text { Kelas } \\
\text { Eksperimen }\end{array}$ & 3,15 & 7,81 & $\begin{array}{l}\text { Terdistribusi } \\
\text { normal } \\
\text { Terdistribusi } \\
\text { Kelas }\end{array}$ \\
$\begin{array}{l}\text { Kontrol } \\
\text { Kormal }\end{array}$
\end{tabular}

Berdasarkan hasil uji normalitaspada Tabel 3 diketahui nilai $X^{2}$ Hitung $<X^{2}$ tabel sehingga dapat disimpulkan keduanya berasal dari populasi yang terdistribusi normal.
Uji homogenitas pada penelitian ini menggunakan uji statistik Fisher (Uji F) dengan taraf signifikansi $a=0,05$. Uji homogenitas dilakukan untuk melihat apakah data berasal dari varians yang sama atau tidak.

TABEL 4 HOMOGENITAS DUA VARIANS TES AKHIR (POSTTEST) KELAS

\begin{tabular}{llllll}
\multicolumn{8}{c}{ EKPERIMEN DAN KELAS KONTROL. } \\
\hline No. Kelas & $\begin{array}{l}\text { Nilai } \\
\text { varian } \\
\mathrm{s}\end{array}$ & $\begin{array}{l}\text { Varians } \\
\text { hitung }\end{array}$ & $\begin{array}{l}\text { Nilai F } \\
\text { table } \\
(\mathrm{a}= \\
0,05)\end{array}$ & Keputusan \\
\hline 1 & $\begin{array}{l}\text { Kelas VIII B1 } \\
\text { (Ekperimen) } \\
\text { Kelas VIII B3 } \\
\text { (Kontrol) }\end{array}$ & 9,89 & 1,04 & 1,98 & $\begin{array}{l}\text { Kedua } \\
\text { data } \\
\text { homogen }\end{array}$ \\
\hline
\end{tabular}

Berdasarkan hasil uji homogenitas pada Tabel 4 dengan taraf signifikansi $(a=0,05)$, dari data tersebut terlihat bahwa $F_{\text {hitung }}$ lebih kecil dari $F_{\text {tabel, }}$ maka berdasarkan kriteria pengambilan keputusan dapat disimpulkan bahwa tidak terdapat perbedaan varians antara kelas eksperimen dan kelas kontrol atau dengan kata lain varians antara kelas eksperimen dan kelas kontrol adalah sama atau homogen.

Uji hipotesis dilakukan setelah diperoleh bahwa data hasil belajar Antara kelas ekperimen dan kelas kontrol berdistribusi normal dan homogen. Uji ini digunakan untuk memastikan apakah hipotesis yang dilakukan dapat diterima atau tidak. Uji t tersebut diperoleh berdasarkan data tes akhir. hasil dapat dilihat pada Tabel 5.

TABEL 5 UJI BEDA RATA-RATA (DUA PIHAK) TES AKHIR KELAS EKSPERIMEN DAN KELAS KONTROL

\begin{tabular}{|c|c|c|c|c|c|}
\hline No. & Kelas & $\begin{array}{c}\text { Nilai } \\
\text { rata- } \\
\operatorname{rata}(\bar{X})\end{array}$ & $\mathrm{t}$ hitung & $\begin{array}{c}\mathrm{t} \\
\text { table }\end{array}$ & Keputusan \\
\hline 1 & $\begin{array}{l}\text { Kelas } \\
\text { Eksperimen }\end{array}$ & 12,87 & \multirow{2}{*}{2,57} & \multirow{2}{*}{1,67} & \multirow{2}{*}{$\begin{array}{c}\mathrm{H}_{1} \\
\text { diterima }\end{array}$} \\
\hline 2 & $\begin{array}{l}\text { Kelas } \\
\text { Kontrol }\end{array}$ & 11,16 & & & \\
\hline
\end{tabular}

Uji t yang digunakan untuk hipotesis ini adalah uji-t dua pihak. Uji ini digunakan untuk memastikan apakah hipotesis yang diajukan dapat diterima atau ditolak.

Kriteria $\mathrm{H}_{0}$ diterima jika $t_{\text {hitung }}<\mathrm{t}_{\text {tabel }}$ dan $\mathrm{dk}$ $=\left(n_{1}+n_{2}-2\right)=24+24-2=46$ pada taraf nyata $a=0,05$, untuk harga $t$ lainnya $H_{0}$ ditolak. Dari daftar distribusi diperoleh $t_{\text {tabel }}=$ 1,67 sedangkan dari hasil perhitungan uji-t diperoleh nilai $t_{\text {hitung }}=2,57$ yang berada di luar daerah penerimaan $\mathrm{H}_{0}$. Hal ini berarti $t_{\text {hitung }}>$ $t_{\text {tabel }}=2,57>1,67$; dengan demikian $\mathrm{H}_{0}$ di tolak dalam taraf nyata $\mathrm{a}=0,05$ dan $\mathrm{H}_{1}$ diterima. Dengan demikian $\mathrm{H}_{0}$ ditolak dan $\mathrm{H}_{1}$ diterima, dan dapat disimpulkan bahwa terdapat pengaruh hasil belajar fisika antara kelompok 
siswa yang mengikuti Thinking Aloud Pair Problem Solving (TAPPS) dengan model konvensional. Artinya, bahwa Thinking Aloud Pair Problem Solvingmempengaruhi hasil belajar siswa.

\section{B. Pembahasan}

Penelitian ini bertujuan untuk mengetahui ada tidaknya pengaruh hasil belajar fisika dengan model pembelajaran thinking aloud pair problem solving pada siswa kelas VIII. Kegiatan pembelajaran dilakukan sebanyak 6 kali pertemuan terdiri dari 4 kali tatap muka di kelas dan 2 kali pertemuan untuk pretest dan postest di kedua kelas baik kelas kontrol maupun kelas eksperimen.

Analisis data posttes bertujuan untuk mengetahui ada tidaknya pengaruh hasil belajar fisika antara kelompok siswa yang mengikuti model pembelajaran thinking aloud pair problem solving dengan kelompok siswa yang mengikuti model pembelajaran konvensonal pada kelas VIII SMP Negeri 14 Palu. Setelah dianalisis, data posttes berdistribusi normal dan memiliki varians yang homogen, kemudian dilakukan uji statistik dan didapatkan bahwa hasil belajar fisika berbeda, kelompok siswa yang mengikuti model pembelajaran thinking aloud pair problem solving lebih tinggi hasil belajarnya dibandingkan dengan kelompok siswa yang mengikuti model pembelajaran konvensonal.

Berdasarkan hasil pretest dan posttest pada kelas eksperimen dan kelas kontrol bahwa pada skor rata-rata Pretest kelas eksperimen adalah 9,00dengan standar deviasi 3,14 sedangkan untuk kelas kontrol adalah 7,33 dengan standar deviasi 3,07. Dengan menggunakan uji-t dua pihak diketahui bahwa kedua kelas yang dijadikan sampel penelitian yaitu kelas eksperimen (VIIIB ${ }^{1}$ ) dan kelas kontrol (VIIIB ${ }^{3}$ ) memiliki kemampuan yang hampir sama. Setelah diberikan perlakuan pada kelas dengan model pembelajaran TAPPS diperoleh kemampuan akhir dari hasil posttest pada kelas eksperimen memiliki skor rata- rata 12,87 dengan standar deviasi 3,06 dan kelas kontrol dengan skor 11,16 dengan standar deviasi 2,79 . Sehingga kelas eksperimen dalam pembelajaran menggunakan model pembelajaran thinking aloud pair problem solving memiliki hasil belajar yang lebih tinggi dibanding kelas kontrol yang dalam pembelajaran menggunakan model pembelajaran langsung.

Berdasarkan analisis kuantitatif, hasil uji normalitas pretest dan posttest kelas eksperimen dan kelas kontrol keduanya berdistribusi normal karena memenuhi kriteria penerimaan $\mathrm{x}$ 2hitung $<\mathrm{X}$ 2tabel. Selanjutnya hasil uji homogenitas disimpulkan bahwa tidak terdapat perbedaan varians antara kelas eksperimen dan kelas kontrol atau dengan kata lain kedua kelas dikatakan homogen.

Selanjutnya, untuk melihat perbedaan hasil belajar siswa menggunakan uji perbedaan ratarata. Sebelum melakukan uji perbedaan syarat yang harus dipenuhi adalah data harus berdistribusi normal dan homogen. Oleh karena data yang diperoleh dari perhitungan terdistribusi normal dan homogen, maka dilakukan uji perbedaan rata- rata menggunakan uji-t (dua pihak). Tabel 4.4 menunjukkan bahwa nilai $t_{\text {hitung }}=2,57>t_{\text {tabel }}=$ 1,67 . Sesuai dengan kriteria penerimaan, maka dapat dikatakan bahwa rata- rata hasil belajar antara siswa kelas eksperimen lebih baik daripada kelas kontrol. Dengan demikian $\mathrm{H}_{0}$ ditolak dan $\mathrm{H}_{1}$ diterima hal ini menunjukkan bahwa terdapat perbedaan yang signifikan antara rata-rata nilai kelas eksperimen dan kelas kontrol.

Pada pembelajaran thinking aloud pair problem solving memiliki beberapa tahap, diantaranya. Tahap pertama siswa diberi arahan dengan menjelaskan pembelajaran thinking aloud pair problem solving kemudian siswa dibagi menjadi beberapa kelompok dimana tiap kelompok terdiri dari dua siswa dan tiap kelompok menentukan siapa yang dahulu menjadi problem solver dan listener di kelompok tersebut.

Pada tahap kedua, peneliti mempersiapkan pembelajaran dengan menciptakan keingintahuan dan kesenangan pada siswa tentang materi pembelajaran ini bertujuan untuk membangun pengetahuan awal siswa. Peneliti memberikan apersepsi dan motivasi pada siswa melalui contoh-contoh materi gaya dan penerapannya dalam kehidupan seharihari. Respon yang diberikan siswa pada tahap ini adalah mendengarkan penjelasan peneliti dengan penuh rasa penasaran. Dengan rasa penasaran ini membuat siswa menjadi lebih aktif dan meningkatkan keingintahuan siswa.

Pada tahap ketiga siswa bekerja secara kelompok ini dilakukan dengan memberikan LKS (lembar kerja siswa) yang mengantarkan mereka untuk mejawab beberapa pertayaan yang telah diberikan pada pembelajaran, dalam hal ini yang menjawab pertayaan tersebut adalah yang bertugas sebagai problem solver dimana dalam menjawab soal problem solver harus menyatakan jawabnnya dengan lisan dan tulisan dari membacakan hingga penyelesaian soal. Kemudian tugas dari listener adalah mendegarkan problem solver dalam menyelesaikan pertayaan kemudian 
menangapai bila ada jawaban yang kurang jelas tetapi tidak di perkenangkan membantu problem solver dalam menjawab atau menyelesaikan pertayaan. Pada tahap ini terlihat sikap positif dan semangat yang lebih terlihat pada siswa karena siswa dituntut tidak hanya diam, tetapi menyalurkan kemampuan motorik mereka terlihat dalam diskusi kelompok. Setalah problem solver selesai mengerjakan tugasnnya peneliti memberitahukan agar bertukar peran.

Pada tahap ke empat, siswa diarahkan untuk menyajikan hasil jawabannya dengan mempersilahkan kelompok yang di tunjuk oleh guru untuk mempersentasikan hasil dari pekerjaannya. Guru bersama siswa melihat persamaan dan perbedaan yang ada. Peran guru sangat dibutuhkan sebagai fasilitator untuk menangkap jawaban yang disepakati bersama.

Pada tahap kelima, peneliti menanamkan arti penting dari kecintaan terhadap belajar. Pada tahap ini peneliti bersama-sama dengan siswa membuat kesimpulan hasil pembelajaran. Selain itu peneliti juga memberikan tugas kepada siswa yang di selesaikan diluar jam pelajaran.

Berdasarkan hasil dari penelitian tersebut diketahui adanya pengaruh positif model pembelajaran thinking aloud pair problem solving yang mampu mengubah cara belajar siswa menjadi aktif serta dapat meningkatkan hasil belajar fisika. Saat kegiatan belajar mengajar berlangsung memberikan pengalaman tersendiri kepada siswa dalam pembelajaran dan praktik. Suasana belajar menjadi menyenangkan, sehingga siswa maupun guru menikmati proses pembelajaran. Inilah salah satu kelebihan dari model pembelajaran thinking aloud pair problem solving yang membuat hasil belajar lebih baik karena siswa dapat menuangkan pengetahuannya sendiri dalam suatu masalah yang di berikan oleh guru dan juga siswa bisa membagi pengetahuannya dengan teman kelompoknya, sehingga siswa termotivasi satu sama lain. Dengan demikian dapat meningkatkan perhatian siswa untuk belajar fisika.

Hasil penelitian ini relevan dengan hasil penelitian yang dilakukan oleh Setiani (2016) dengan judul "Pengaruh Model Pembelajaran Thinking Aloud Pair Problem Solving (TAPPS) terhadap Kemampuan Komunikasi Matematis Siswa SMP" Dari analisis data hasil penelitian, diperoleh kesimpulan : 1) kemampuan komunikasi matematis siswa yang memperoleh pembelajaran dengan model Thinking Aloud Pair Problem Solving (TAPPS) lebih baik daripada kemampuan komunikasi matematis siswa yang memperoleh pembelajaran konvensional, 2) secara keseluruhan model pembelajaran Thinking Aloud Pair Problem Solving (TAPPS) mendapatkan sikap positif dari siswa. Begitu pula hasil penelitian Pratiwi (2014) Hasil penelitian mengungkapkan bahwa terdapat pengaruh model pembelajaran terhadap kemampuan berpikir analitis matematis siswa. Model thinking aloud pair problem solving memberikan kemampuan berpikir analitis matematis yang lebih baik.

Hasil penelitian ini sejalan dengan penelitian yang dilakukan oleh Wijayanti (2013)Hasil penelitian menunjukkan mean post test kelas eksperimen sebesar 80.27 dengan standar deviasi 4.448 yang berarti lebih baik dari mean kelas kontrol sebesar 69.47 dengan standar deviasi 5.303, dan nilai sig 0,000 < 0,05. Sehingga dapat disimpulkan bahwa $H_{1}$ diterima dan $\mu 1>\mu 2$, yaitu prestasi belajar kelas eksperimen lebih baik daripada prestasi belajar kelas kontrol. Dengan demikian dapat disimpulkan bahwa prestasi belajar siswa dengan model pembelajaran TAPPS lebih baik dibandingkan dengan metode pembelajaran konvensional. Hal ini menunjukkan bahwa adanya pengaruh model pembelajaran TAPPS (Thinking Aloud Pair Problem Solving) terhadap prestasi belajar siswa.

Namun selain daripada keunggulan dari model ini, penggunaan model pembelajaran thinking aloud pair problem solving (TAPPS) juga tidaklah mudah. Dimana sekolah tempat penelitian memiliki karakteristik kelas besar, jadi guru agak kesulitan melakukan bimbingan perkelompok dikarenakan jumlah kelompok yang banyak, Sebagaian siswa kemampuan berhitung, seperti penjumlahan, pengurangan, perkalian, dan pembagian masih rendah sehingga cukup menghambat jalannya proses pembelajaran selama penelitian, dan kontrol terhadap kemampuan subjek penelitian hanya meliputi variabel model thinking aloud pair problem solving (TAPPS) dan hasil belajar siswa. Variabel lain seperti minat, motivasi, inteligensi, lingkungan belajar, dan lain-lain tidak terkontrol. Karena hasil penelitian dapat saja dipengaruhi variabel lain di luar variabel yang ditetapkan dalam penelitian ini.

\section{KESIMPULAN DAN SARAN}

Berdasarkan hasil analisa data penelitian disimpulkan bahwaterdapat pengaruh hasil belajar fisika antara model pembelajaran thinking aloud pair problem solving (TAPPS) dengan model pembelajaran langsung pada siswa kelas VIII SMP Negeri 14 Palu. Hal ini 
ditunjukkan dengan kriteria penerimaan Ho adalah $t_{\text {hitung }}=2,57>t_{\text {tabel }}=1,67$. Hasil $u j i$ hipotesis ini memperlihatkan bahwa harga $t_{\text {hitung }}$ tidak berada di dalam daerah penerimaan Ho atau dengan kata lain $\mathrm{H}_{1}$ diterima pada taraf nyata $a=0,05$, secara kuantitatif untuk kelas eksperimen lebih unggul dari kelas kontrol. Dengan demikaian dapat dinyatakan bahwa hasil belajar dengan mengunakan model pembelajaran thinking aloud pair problem solving (TAPPS) berbeda secara signifikan dari kelompok siswa yang mendapatkan pembelajaran konvensional pada kelas VIII SMP Negeri 14 Palu.

Berdasarkan kesimpulan ada beberapa saran yang dapat dikemukakan: (1) Pada penelitian

\section{DAFTAR PUSTAKA}

[1] Handoko, K. (2014). Penerapan model pembelajaran thinking aloud pair problem solving (TAPPS) dalam meningkatkan kemampuan analisis siswa pada mata pelajaran ekonomi. Universitas Pendidikan Indonesia. Jakarta

[2] The Liang Gie. (1987). Cara Belajar Yang Efisisen. Yogyakarya: Liberty.

[3] Slameto, (2003). Belajar dan Faktor-faktor yang Mempengaruhinya. Jakarta : PT RinekaCipta.

[4] Wina S. (2010). Strategi Pembelajaran Berorientasi Standar Proses Pendidikan. Jakarta: Kencana

[5] Sugiyono, (2010). Metode Penelitian Kuantitatif, Penelitian Kualitatif, dan $R \& D$. Bandung: Alfabeta. ini pembelajaran dengan menggunakan model pembelajaran thinking aloud pair problem solving (TAPPS)hanya terbatas pada materigaya dan penerapannya, alangkah baiknya jika ada penelitian lanjutan dengan menggunakan model yang sama pada pokok bahasan lainnya, untuk mendapatkan masukan yang lebih lengkap agar pengaruh model Tappsini jelas teramati.(2) Guru yang hendak menggunakan model pembelajaran thinking aloud pair problem solving (TAPPS) dalam pembelajaran di kelas diharapkan dapat mendesain pembelajaran dengan seefektif mungkin sehingga pembelajaran bisa selesai tepat waktu. 